\title{
CERTAIN CONSIDERATIONS REGARDING THE ATTRIBUTIONS OF THE GUARDIANSHIP COURT IN THE PROTECTION OF THE INDIVIDUALS
}

\author{
Daniela Cristina Creţ* \\ "Vasile Goldiș" Western University of Arad, Faculty of Law, Romania \\ E-mail: danacristinacret@yahoo.com
}

(Received: August 2019; Accepted: October 2019; Published: November 2019)

\begin{abstract}
The issue of protecting the natural persons has been triggering a lot of interest due to the need for providing them with proper means for this purpose. In Romania, the court of guardianship and family plays an important role in protecting this category of persons, court established as a result of the entering into force of the new Romanian Civil code in 2011. The legal norms distinguish between the prerogatives of this court on the protection of the major persons and its attributions in this matter towards the minors. Further on, it will be analyzed certain prerogatives of the guardianship and family court meant for the minor persons.
\end{abstract}

Keywords: protection, guardianship and family court, parental authority, General Directorate of Social Care and Child's Protection.

\section{Fundamentals on the guardianship and family court}

The protection of the natural person in the Romanian legislation can be analyzed under two aspects: the protection of the minor natural people and the protection of the full-aged people.

According to the provisions of the Law no. 272/2004, republished, the juridical means assigned for the protection of the minors are concerning the protection and the promotion of children's rights: the parental authority, the tutelage, the special guardianship, the measures of special protection, but also the adoption [1]. To these means, the Civil Code adds also minor's placement under court interdiction. Concerning the protection of the full-aged people, the legal norms establish as protection means: putting under court interdiction, guardianship, social assistance of the elders [2], and protection of the people with psychical disorders [3].

\footnotetext{
${ }^{*}$ Corresponding author: Daniela Cristina Creţ. E-mail: danacristinacret@yahoo.com
} 
We can notice among the authorities that play a fundamental part in the natural person's protection, alongside the General Directorate for Social Care and Child's Protection, the guardianship and family court.

In this paper it is analyzed the attributions of the guardianship and family court concerning the minors, and in a future study, it will be tackled the approach regarding its attributions towards the full-aged people.

The normative acts which rule the minors' protection in Romania are: the Constitution, the Civil Code entering into force in 2011, the Law no. 272/2004, republished, on the protection and promotion of the children's rights [4], and also the Law no. 273/2004 on the procedure of adoption [5] and under certain procedural aspects, the Civil Procedural Code.

While the Constitution of Romania legitimates the children's rights, the Civil Code is considered to be the general frame regulation which settles down the means of minors' protection, the habilitated persons/ body to concede it and it briefly presents their attributions in this matter, and the Law no. 272/2004, republished, settles in detail the prerogatives of the public authorities, the private certified bodies, and those of the moral and natural persons that are liable for children's protection, and it stipulates the aspects of procedural matter concerning the implementation of these means as well.

Concerning the minors' protection, the basic principle consists in child's higher interest, which both any other normative act, drafted in order to observe and promote children's rights, should relate to, but also any other judicial act issued or, in case, concluded in the matter; in the same time, this principle must be applied with priority in all endeavors and decisions concerning the children, adopted by the public authorities and by the private authorized organizations, but also in the litigations solved by the Courts of Law [6]. The superior child's interest involves the child's right to both normal physical and moral development, but also to socialaffective balance and to a family life (art. 2 from Law no. 272/2004).

The Romanian ruler pays a special attention to the minor persons, which also results from the provisions of the Law no. 304/2004, republished, on the judicial organization [7], normative act which stipulates in art. 39 par. 2 that: "There will be organized in the courts of law, departments or panels of judges for minors and family"; but it doesn't exclude the possibility of functioning, in the courts of appeal and courthouses, of some specialized departments or panels of judges for files with minors and family, depending on the complexity and the number of cases.

Furthermore, the Law no. 304/2004, republished, also foresees the functioning of some courthouses for minors and family (art. 37, art. 40 from the Law 304/2004). Nevertheless, the element of major novelty in this matter consists in the establishment of some specialized court in solving the causes which target the

96 sciendo Journal of Legal Studies Volume 24 Issue 38/2019 ISSN 2457-9017; Online ISSN 2392-7054.

Web: publicatii.uvvg.ro/index.php/jls. Pages $95-110$ 
Creț, D.C., (2019)

minors, court called Family and Guardianship Court through the current Civil Code (art. 107, art. 265) that came into force on October $1^{\text {st }}, 2011$. In addition, this normative act assigns protection means for the natural person, in generally, in the competence of guardianship court which, thus, will replace the authority for guardianship.

The authority for guardianship was the body having tasks on setting and organizing the guardianship, the monitoring, the control and the guidance of the minor's protection activity and of other incapacitated persons, such as patients with mental disorders put under interdiction through a court order, or of certain elderly persons. In this context, we must keep in mind the provisions of the art. 265 Civil Code, which rules the competence of the guardianship court [8] regarding all measures set by the Second Book - "On the Family", in court jurisdiction being comprised all disputers on the enforcement of the norms of the above-nominated book, and also the measures on child protection provided by special laws.

There are also relevant in this matter the provisions of the art. 76 from the Law 76/2012 for the enforcement of the Law no. 134/2010 concerning the Code of Civil Proceeding, as well as for the amendment and the completion of some related normative acts which stipulates that, until organizing the family and guardianship courts, the courthouses or, where applicable, the specialized courts or courthouses for minors and family are going also to be panels for guardianship and family, with the competencies established according to the Civil code, Code of Civil Proceeding, the current law, but also by the special regulations which are in force. Moreover, we can notice the stipulations of the art. 94 par. (1), article a) of the Code of Civil Proceedings which assigns in material competence of the judges the requests submitted according to the Civil Code in the competence of the guardianship and family court and family court, excepting the situations when the law provides otherwise. Among the exceptional situations, we can highlight those settled by the dispositions of the art. 133 from the Law no. 272/2004 which assign in the material competence of the court the disputes stipulated by this normative act on the establishment of the measures of special protection, and in territorial competence, competencies are assigned to the court where the child resides, and when this fact is unknown to the court in which territorial area the child was found; and also those mentioned in the art. 84, par. (3) corroborated with art. 86 from the Law no. 273/2004 on the adoption, which highlights from material point of view the competence of the specialized courts in ruling the requests mentioned by this law [9], and also the requests of ceasing the adoption, and from territorial point of view the competence of the court in which the adopter has his residence [10]. 


\section{Aspects concerning the attributions of the family and guardianship court} regarding the parental authority

The attributions of the guardianship and family court may be analyzed related to the various means of protection and the normative acts regulating them.

In this regard, synthesizing of the guardianship court, the provisions of the Law no. $272 / 2004$ provide clearly that, having in mind, with priority, the higher child's interest, the court represents the only competent authority which can rule on:

a) the person who exerts the parental rights and duties when the child lacks temporary or permanently parental protection.

b) how the parental rights and obligations are going to be exerted.

c) total or partial termination of the parental rights

d) awarding again parental rights.

Regarding the attributions of the guardianship court exerted towards the child who lacks temporary or permanently, the parental protection, I will discuss this matter below in a sub paragraph of this paper.

In relation to the exercise of parental authority, corroborating the provisions of the Law no.272/2004 from the Civil Code [art. 498 par. 1)] with those of Code of Civil Proceedings [art. 94 par. 1 a)] we can see that the court where the parent / parents has/ have the residence is the only one competent to rule in first instance the demands assigned by the legal norms to the guardianship and family court, except for the situations referred explicitly by the law.

It can be noticed that the phrase 'parental authority' designates the set of rights and duties that concern the person, and also the goods of the child and belong equally to both parents [11] [art. 483 par. (1) Civ. Code].

The norms of Civil Code foresee that the parental authority will be exerted together and equally by both parents [art. 503 par. 1)]. In the same way, the authority will be exerted towards the child who comes from out of the marriage of whose parenthood was settled in the same time or successively for both parents if they live together [art. 483 par. 1 Civ. Code].

In the event that the child's parents from out of marriage do not live together, but also in case when the court is invested with a request of establishing of the parenthood, the guardianship court must decide on the way the parental authority can be exerted, through the enforcement of the norms in the divorce matters.

Nevertheless, if the highest interest of the child is respected, and they get the approval of the guardianship court, the parents can agree regarding the way they will exert the parental authority or regarding the adoption of a protection action for the child. Same as in other cases where measures concerning them are taken, the hearing of the child is mandatory, thus enforcing the stipulations of the art. 264 Civ. Code (art. 506 Civ. Code)

98 Sciendo Journal of Legal Studies Volume 24 Issue 38/2019

ISSN 2457-9017; Online ISSN 2392-7054.

Web: publicatii.uvvg.ro/index.php/jls. Pages $95-110$ 
Creț, D.C., (2019)

Certain considerations regarding the attributions of the Guardianship Court in the protection of the individuals

In fact, the wording of article 264 par. (1) Civil Code, corroborated with article 29 of Law No 272/2004 states, in judicial or administrative proceedings concerning the child, the obligation to hearing of the minor, who has reached the age of 10, but do not exclude any possibility of hearing the child who has not reached the age of 10 years, with the assumption that the competent authority considers this necessary for the solution of the case. The same legal text also stipulates the connotations on child's right to be heard, this involving also the child's possibility to ask and receive any information, in relation to its age, to express an opinion and to be informed of the consequences that this could cause, if observed, and as well on the consequences of any decision concerning it. The legislator enforces each child's ability to ask to be heard, under the specified terms, providing that the rejection of the request made in this regard by the competent authority in the raw material shall be motivated.

It is further noted also, that the heard child will be judged considering his / her age and level of maturity. The text of article 264 Civil Code lays down also the fact that there are incidental also the legal norms on the consent or presence of the child in proceedings referred to him / her, and on the provisions with regard to the appointment of a representative by the court in the event of conflict of interests.

Legal rules shall also provide the possibility of exercising parental authority by one parent. In this respect, in addition to the specific situations listed in article 507 Civil Code in which it operates (e.g. death of one of the parents, restraining orders for one of the parents, the termination of the exercise of parental rights for one of the parents, etc.), the exercise of parental authority by one parent may be ruled by the competent guardianship court in the event of: alcoholism, mental disorder, drug dependence of the other parent, parent's violence against the child or the other parent, convictions for offenses of human trafficking, drug trafficking, sexual offenses, offenses of violence, as well as any other reason related to risks for the child, which would arise from the exercise by the respective parent of the parental authority [art. 36 par. (7) of Law No 272/2004]. The Court shall rule in guardianship court also on existence of disagreements between the parents on the exercise and achievement of the parental rights and duties. Thus, the Court may rule, having regard to the child's interest, after hearing both parents, and taking under consideration the conclusions of the psycho-social report. Similar to the other cases of enforcing the measures for the protection of the minor, the instance has to hear the child, and in doing so it enforces the provisions of article 264 Civil Code (art. 36 of Law no. 272/2004, corroborated with art. 486 Civil Code).

We can also notice important attributions of the guardianship courts concerning child's domicile. In this regard, the norms of the article 496 par. (1) Civil Code set the minor child's domicile with the parents. If misunderstandings in this matter 
arise between the parents, the guardianship court rules the child's domicile to be with one of the parents according to the findings of the psycho-social inquiry, to the parents' hearings, and hearing also the respective child if he/ she is 10 years old, thus enforcing the provisions of the Article 264 C. Civil Code. [art. 21 of the Law no. 272/2004, corroborated with art. 496 par. (3) Civil Code]. Among the criteria on the basis of which the Court of guardianship shall evaluate the child's interest may be noted the following: (a) the availability of each parent to involve the other parent in the decisions with respect to the child and to comply with the parental rights of the other parent unit;

(b) the housing situation in the past 3 years of each of the parent;

(c) the distance between the house of each of the parent unit and the institution which provides education to the child.

These criteria shall be taken into account in appropriate manner also in the situations where the minor's home is to be set with thirds or in a service of special protection.

There are relevant to the provisions of article 496 par. (5) Civil Code conferring the guardianship court the prerogative to limit the right for the parent with whom the child does not dwell currently to have personal connections with the minor at the respective parent's home if this limitation corresponds to the child's higher interest. We appreciate that such limitation can be justified when the respective parent is violent, alcoholic or has a severe mental condition.

As a rule, the change in the minor's domicile with effects on the exercise of the parental authority or of certain parental rights has to involve the other parent's prior agreement [art. 497 par. (1) Civil Code]. If the disagreement between the parents intervenes on this aspect, the guardianship court rules, considering the child's higher interests, on the basis of the conclusions of the psycho-social report, whilst hearing the the parents and the child in question, and enforcing the provisions of article 264 Civil Code [art. 497 par. (2) Civil Code]. It should be noted that this time the law-maker has not made the statement that the child has to be heard if the child is 10 years old, as provided for in the case in which occur misunderstandings between the parents concerning the child's home. The absence of this indication may be determined by the fact that the legislator appreciated that the minor can understand even before the anniversary of 10 years the consequences of changing the dwelling: difficulty in maintaining relationships with the parent with whom he does not live steadily, a change in the institution of education, changing the eventual friendships etc.

An important children's right is the right to education. With regard to this right, the provisions of article 51 of the Law on the protection and promotion of children rights are eloquent as they state the child's right "to receive an education that

100 S sciendo Journal of Legal Studies Volume 24 Issue 38/2019

ISSN 2457-9017; Online ISSN 2392-7054.

Web: publicatii.uvvg.ro/index.php/jls. Pages $95-110$ 
Creţ, D.C., (2019)

would allow for child's development, skills and his personality, under nondiscriminatory conditions". The right to choose the kind of education to be given to their children is provided by this law first to their parents, to them being incumbent as well the children's enrolment at school and to ensure attendance at the regular school courses. The norms of the Civil Code and those of the Law no. 272/2004 grant powers to the guardianship court with regard to the exercise of this right, too. Thus, in the case when child's parents oppose his / her request to change the type of education or vocational training or the dwelling required for completing the studies or the vocational education, the child who has reached the age of 14 years may request the court of guardianship the consent to change the type of education or vocational training or the dwelling required for completing the studies or the vocational education [12]. As in other cases in which it is notified, the appellate guardianship court rules according to the psyso-social inquiry report, after child's hearing, which is mandatory, in compliance with the provisions of article 264 Civil Code (art. 498 Civil Code, corroborated with art. 51 of Law no. 272/2004).

The provisions of the laws grant to the guardianship court powers also regarding the exercise of parents' obligation to support the child. On this obligation, article 499 Civil Code par. (1) stipulates father's and mother's joint obligation to support their minor child by providing necessities of life, and also of education, learning, and professional training. We are rather intrigued by the provisions of par. (2) of article 499 C. Civil Code which stipulate that, based on the assumption that the minor has own insufficient income, "parents have the obligation to provide the child with the necessities for upbringing, education and professional training." Per a contrario, we can deduct that, in case the minor child has own sufficient income, parents do not have the obligation to support him/ her; or, as it is obvious from the provisions of article 499 par. (1) of the Civil Code, but also from those of article 47 of Law no. 272/2004, parents' main obligation is precisely that of supporting the child. In this respect, article 47 of the law in question highlights child's right to a standard of living that ensures the development of physical, mental, spiritual, moral and social development, but also the parent's or, as the case may be, legal guardians' responsibility, to ensure the best living conditions required for children's upbringing and development; the same legal text specifies that the parents' duty is to ensure for their children a home, the conditions necessary for upbringing, education, learning, training, and also to a healthy living environment. As a matter of fact, in substantiating the opinion that parents owe their children to support them regardless on child's income, we can also emphasize the norms of par. (3) Article 499 Civil Code which provides for the obligation of parents to provide for their major child's support until the age of 26 years old, provided that the latter continues its studies, until the studies completion, but also those of article 
500 Civil Code governing the patrimonial independence of the assets between the parent and child patrimony, stipulating that the parent has no right on child's assets, nor the child on parent's assets, except for the right to inheritance and support.

Returning to the court attributions on the exercise of the obligation of support, it should be noted that in the case of disagreements between parents with regard to the scope of the obligation for support and ways to carry it out, and also to each parent's contribution, these matters are ruled by the guardianship court considering the psycho-social inquiry report [article 499 par. (4) Civil Code].

There are also significant in this matter the provisions of article 524 Civil Code, which lay down that only the person in need, not being able to support oneself by its work or assets, may be creditor for support. We also consider surprising in the context of the above exposed, also the provisions of paragraph (1) of article 525 Civil Code which, in addition to the provisions of paragraph (2) of article 499 Civil Code, provided that the minor which asks for support from the parents is in need under the terms where he/ she cannot support himself/ herself, even owing its own assets. Per a contrario, it is deducted that, when the minor child can support itself, whether or not holding assets or being in need, that person is not in need, so no support owed to it which is contrary to the provisions of article 499 par. (1) and par. (3) of the Civil Code, but also in those of article 47 of the Law no. 272/2004.

In this context, taking into consideration the arguments above, but also the provisions of article 48 par. (1) of the Constitution of Romania, which provide that: "The Family is founded on the freely consented marriage of the spouses, their full equality and the right and duty of the parents to ensure the upbringing, education and instruction of their children", but also those of article 484 Civil Code which foresees that: "Parental authority shall be exercised until the date when the child acquires the full exercise capacity" and, as general rule, the full capacity to exercise is to be acquired at the age of 18 years, we propose, by law ferenda, the amendment of the provisions of article 499 par. (2) Civil Code, but also of those of article 525 par. (1) Civil Code. In this respect, we appreciate that in paragraph (1) of article 499 Civil Code the requirement that "the minor may have his/ her own income which is not sufficient" should be removed, and its contents to restrict strictly to the wording: "Parents have the obligation to ensure the minor the necessary conditions for child's upbringing, education and professional training". Regarding the provisions of article 525 par. (1) Civil Code, we appreciate that this legal text, by removing the terms "if it is not possible to support itself from employment, even when owing assets", should have the following content: the minor who asks support from his parents is presumed to be in need. We believe that the minors constitute a special category, the exception to the rule, they cannot

102 Sciendo Journal of Legal Studies Volume 24 Issue 38/2019 ISSN 2457-9017; Online ISSN 2392-7054.

Web: publicatii.uvvg.ro/index.php/jls. Pages $95-110$ 
Creț, D.C., (2019)

Certain considerations regarding the attributions of the Guardianship Court in the protection of the individuals

be comprised in the category of persons supporting the family referred to in article 524 Civil Code: "it is entitled to support only the person who is in need to the extent that it maintains of work or of his assets." We substantiate this opinion on the fact that the minors are a vulnerable category of persons, the latter needing upbringing, education, training and guidance until the age of majority, regardless of whether they work or not, they have assets or not. At the same time, the minors who have not reached the age of 15 years may not be employed [art. 49 par. (4) of the Constitution of Romania], and the work program of the minors up to 18 years is limited to 6 hours / day [13] (art. 112 Code of Labor). Considering these aspects and their lack of experience, it is rarely known that their wages would enable them to support themselves up to the age of majority.

The Romanian legislator, proving clemency toward parents with a precarious patrimonial situation, rules that the guardianship court may agree that the minor's support is to be ensured by capitalizing the goods owned by the minor, except for those of basic necessities, with the assumption that the parents may not support the child without endangering their own existence [article 525 par. (2) Civil Code].

In what concerns the arrangements for carrying out the obligation for support, article 530 par. (1) Civil Code stipulates that it is to be executed in nature, by providing necessities of life and, depending on the case, the expenses for education, learning and training. In the assumption that the obligation for support is carried out voluntarily, in nature, the guardianship court is to decide the execution of it under the form of payment of support pension, established in currency.

Tasks of the Guardianship Court are enacted also with regard to the administration of the child's assets. In this respect, though, after being 14 years old, the minor exercises its own rights and obligations, the child still need parents' or guardian body's approval according to law [art. 501 par. (2) Civil Code].

In this context, the powers of the court of guardianship regarding the enforcement, upon request from the local public administration authorities with attribution in child protection, namely the general directorate for social care and child protection, of the sanction to terminate the parental rights may also be highlighted (art. 508 Civil Code, corroborated with article 41 of the Law no. 272/2004). In this respect, from procedural point of view, it should be noted that the public social care service has the obligation to notify immediately the General Directorate of Social Care and Child Protection in order to take measures provided by the law for the situation when, after the visits, it is found that the child's physical, mental, spiritual, moral or social development is in danger. It is incumbent to this directorate to refer the matter to the Court of Justice if it considers that the legal requirements for the sanction of parental rights termination are met.

The terms according to which this sanction could operate target the fact that the

S sciendo Journal of Legal Studies Volume 24 Issue 38/2019

ISSN 2457-9017; Online ISSN 2392-7054. 
parent puts in danger the child's life, health or upbringing by bad treatments caused by the consumption of alcohol or drugs, by abusive behavior, by serious negligence in the performance of his / her duties or by severely harming child's higher interest. Considering the serious consequences of the parent's behavior toward the minor, the settlement of the application with regard to the enforcement of this sanction shall be carried out in emergency, with subpoena sent to the parents and according to the psychosocial inquiry findings. Taking into consideration the fact that persons nurtured by these legal rules are children, the participation of the prosecutor is compulsory [article 508 par. (2) Civil Code, corroborated with article 92 Code of Civil Proceedings].

Even though the scope of the parental rights termination is total and operates on all born children on the date of ruling, if the children's upbringing, education, and training are not in danger, the court may require the enforcement of the sanctions only in respect with certain parental rights or with some children (article 509 Civil Code).

In order not to leave the child without legal protection, the law-maker has provided for the guardianship enforcement in the case when, after the enforcement of the mentioned sanction, the child is to be deprived of both parents' care (article 511 Civil Code). For instance, the child may be in such situation when the termination of parental rights was applied to both parents or when parental authority was exercised by only one of the parents and this sanction was applied to this one.

The civil norms also provide for the possibility of guardianship court to restore the right to exert parental rights if two requirements are met cumulatively: the circumstances leading to the termination of rights ceased, respectively the parent no longer endangers child's life, health and upbringing. At the same time, if it is in the best interest of the child, the above-named Court may allow the parent to have personal connections with the child until solving the application. (article 512 Civil Code).

\section{Aspects on the attributions of the Guardianship and Family Court regarding the guardianship}

The provisions of article 44 of the Law no. 272/2004 institutes the right to alternate protection for any child who lacks, temporarily or permanently, parental care, or who cannot be left in parent's care in order to protect its interests. This protection comprises: the establishment of guardianship, special protective measures stipulated by the above-mentioned law, and also the adoption. When choosing one of this means of protection, the General Directorate of Social Care and Child's Protection must consider the need to provide for certain continuity in child's education, and equally child's ethnical, religious, cultural and linguistic origin.

104 S sciendo Journal of Legal Studies Volume 24 Issue 38/2019 ISSN 2457-9017; Online ISSN 2392-7054.

Web: publicatii.uvvg.ro/index.php/jls. Pages $95-110$ 
Creț, D.C., (2019)

The authority to settle the guardianship is the court (the court of guardianship - our mention) in the territorial jurisdiction of which the child has the domicile or was found (article 45 of Law no. 272/2004).

The natural person's protection by guardianship is carried out by the guardian and by the family board which is a consultative body. It is to be noticed that its prerogatives are to be exerted by the Guardianship Court it the family board is not established (article 108 Civil Code).

According to the article 110 Civil Code the guardianship of the minor shall be established in a situation where both parents are, or depending on the situation, dead, unknown, with parental rights terminated or the criminal penalty of forbidding their parental rights or they are under restraining court order, missing or legally declared dead, but also in the situation when, at the termination of the adoption, the court has ruled the establishment of guardianship.

The provisions of the current Civil Code foresee two ways of appointing a trustee: by the parent through the unilateral act or by contract of mandate, concluded in genuine version, or, as the case may be, by testament [article 114 par. (1)], which is a novelty compared to the old regulatory framework, respectively of the court of guardianship, if no assignment is made from the parent (article 118).

The legal rules also regulate the procedural aspects of the appointment, establishing that the guardian is appointed by the guardianship court in the panel room with trustee's agreement and with final conclusion. It is also stipulated as mandatory the hearing of the minor who is at least 10 years old. It should be noted that the appointment of the trustee involves consultation with the family board in the assumption that the guardianship court has established such board. Trustee must be informed on the panel conclusion which is to be published also at the premises of the guardianship court, and also at the town hall where the minor's domicile is located.

Among the attributions of the Court of guardianship, it is stressed also that of establishing the Family Board (art. 125 Civil Code). 3 relatives or related persons may be part of this consultative body, depending on the degree of relatedness and personal relations with the family of the child, with the exception of the trustee. In the absence of relatives or related persons the court may also appoint other people who are friends with minor's parents or who expressed their interest for the child's situation. Considering the same matters, the Guardianship court may also appoint 2 alternates.

The establishment of the Family Board is to be carried out by trustee's invitation to the minor's domicile sent by the Court of guardianship, ex officio or upon minor's request when being 14 years old, the designated trustee, any other persons who are informed on minor's situation, the persons fulfilling the necessary requirements. 
The appointment of the family board members involves their agreement and the hearing of the minor who is at least 10 years old.

A provision which seems contradictory to us is comprised in the article 135 par. (2) Civil Code with regard to the guardianship exerted by both spouses. This legal text stipulates that: "In the event of one of the parent files for divorce, the court, ex officio, will notify the guardianship court to rule on the guardianship." According to article 915 Code of Civil Proceedings, the filing for divorce is to be submitted to the courthouse in the jurisdiction of which is the last joint residence of the spouses [14], and , in this case, according to article 45 of the Law no. 272/2004, the guardianship court to rule on the guardianship is the court of law in the jurisdiction of which the child has the domicile or was found, namely same courthouse, since the house (and also minor's dwelling) is with his/ her parents [Article 496 par. (1) Civil Code]. Taking into consideration these aspects, we propose the law ferenda, an amendment of paragraph (2) of article 135 Civil Code, with the following wording: "When one of the spouses files for divorce, the guardianship court will settle on the guardianship exercise."

After the appointment of the trustee, and when it is required, of the Family Board, there intervene other significant prerogatives of the guardianship court, which could be emphasized on two levels: healthcare plan of the person in respect of which it has set up this means of protection, namely the plan of the heritage of such person.

As regards the powers of the court of guardianship with respect to the protection of the minor, there are to be noted those related to the residence of the minor (art. 137 Civil Code). Thus, although the rule is that the minor under the guardianship has the domicile with the guardian, subject to the authorization by the Court of guardianship, by exception from the rule, the minor may have another dwelling when the guardian agrees that the minor has a residence established due to its education and vocational training, and, in such case, the guardianship court has to be informed immediately on this, by the guardian.

In the same context, article 138 Civil Code provides that the minor who is not 14 years old cannot change the form of education or vocational training taken on the date of establishing the guardianship without the approval of the guardianship court; in addition, the guardianship court cannot change the type of minor's education, decided by the parents or taken by the minor upon the establishment of the guardianship, against minor's will if the minor is at least 14 years old.

An important principle in matters is, just like for the parental authority, the hearing of the minor by a guardianship court in any decision related to the minor, if the minor is at least 10 years old, as results from the enforcement of the provisions of article 264 Civil Code.

106 S sciendo $\begin{aligned} & \text { Journal of Legal Studies Volume 24 Issue 38/2019 } \\ & \text { ISSN 2457-9017; Online ISSN 2392-7054. } \\ & \text { Web: publicatii.uvvg.ro/index.php/jls. Pages 95 - } 110\end{aligned}$


Creț, D.C., (2019)

Considering the protection of the patrimony owned by a minor under guardianship, there could be stressed the prerogatives of the guardianship court on the inventory and administration of minor's assets.

As regards the inventory of minor's goods, it is noted that Article 140 Civil Code specifies that a delegate of the guardianship courts must verify on site, in the presence of the guardian and the members of the family board, all the assets owned by the minor, drawing up an inventory, which is to be submitted for the approval of the competent guardianship court. In the same time, when performing the inventory, the guardian and the family members have to declare in writing to the delegate of the guardianship court all the claims, debts or other requests which they might have toward the minor. The payment, made voluntary by the guardian or one of the members of the family board, the spouse, a direct relative or their brothers or sisters, of the debts assigned to the minor may be carried out only with the authorization of the competent court of guardianship.

Other provisions on the powers of this Court are regulated by the Civil Code regarding the disposition acts which have been concluded by the guardian (article 144 Civil Code). The acts of alienation, sharing, mortgaging or encumbrance with other real charges of the minor's assets, the waiving of the patrimony rights for the minor, and, also, the valid conclusion of any other acts surpassing the right of administration may be carried out by the guardian only with endorsement from the family board, and authorization from the guardianship court [15]. The guardianship court may notify the prosecutor in order to cancel these acts.

The Civil Code institutes explicit provisions of the authorization given by the court of guardianship (article 145 Civil Code). Thus, the guardianship court shall grant authorization to the guardian only under the terms when the act responds to needs or is useful without any doubt to the minor. In addition, the approval may be given for each act separately, setting out, where applicable, the terms for concluding the document. If the act concluded by the guardian is an act for sale, the authorization shall specify whether the sale will be carried out by common agreement between the parties, by public auction or in any other way. In all cases, the guardianship court may indicate the guardian how to use the sums obtained that way.

The importance of the guardianship as a means of minor's protection sets out an effective and continuous control regarding how the family board and the guardian can perform their duties with regard to the minor and his assets, during the control proceeding, the guardianship court may require the collaboration of the public administration authorities, of the institutions and public services specialized in child protection or of the childcare institutions, where applicable (article 151 Civil Code).

In the same time, annually, the guardian has the obligation to submit to the 
guardianship court a report about how he attended the minor, as well as on the administration of minor's goods.

Another significant missions of the guardianship court aims for the checking of the income and the expenses incurred by the guardian for minor's support and the administration of minor's assets, and, if they are drawn up correctly and genuinely, and their discharging from the guardian.

In the same time, upon the cessation of the guardianship or in case of guardianship retraction, the guardian or, as the case may be, the guardian's heirs are to submit to the guardianship court a general report within 30 days. In addition, in case of guardian's termination due to the guardian's death, the guardianship court may ask the major heirs or their legal representative for a general report. The general report must comprise the status of the revenues and expenses during the last years; it must specify the assets and liabilities, as well as the progress of minor's processes.

Subsequently to the handing over of the assets, the check of the calculations and their approval, the guardianship court will grant the guardian the discharge of management (art. 162 Civil Code).

\section{Conclusions}

One of the institutions with a special role in the enforcement of the means of natural minor person is the court of guardianship and family, also named by the law the guardianship court. The normative acts that currently regulate them are the Civil Code, Law no. 272/2004 on child's protection and promotion of children's rights, respectively Law no. 273/2004 on the adoption.

As it could be noticed during this study, the attributions of this court are numerous, diverse and complex, that is why only the main ones were reviewed.

However, given that these attributions are regulated dispersedly in the mentioned normative acts, we add to the already mentioned law ferenda propositions also that of explicit and unitary regulation of the prerogatives of this court, considering that most of them are aimed to protecting the natural person, in this case those analyzed were those referring to the child, and the children as they represent the future of any nation, are a vulnerable category of the population requiring for special protection. In this regard, we consider appropriate either to draft a special law presenting in extenso these prerogatives or their specific law-making within the Law no. 304/2004 on the juridical organization.

\section{Acknowledgements}

The author thanks the anonymous reviewers and editor for their valuable contribution.

108 S sciendo $\begin{aligned} & \text { Journal of Legal Studies Volume 24 Issue 38/2019 } \\ & \text { ISSN 2457-9017; Online ISSN 2392-7054. } \\ & \text { Web: publicatii.uvvg.ro/index.php/jls. Pages 95 - } 110\end{aligned}$




\section{Funding}

This research received no specific grant from any funding agency in the public, commercial, or not - for - profit sectors.

\section{Author Contributions}

The entire article was written by Daniela Cristina Creț.

\section{Disclosure Statement}

The author has not any competing financial, professional, or personal interests from other parties.

\section{References}

1. Bacaci Al., Dumitrache C. V.., Hageanu C. C., Dreptul familiei, $7^{\text {th }}$, C. H. Beck Publishing House, Bucharest, 2012

2. Bodoaşcă T., Unele consideraţii critice în legătură cu procedura divorţului în reglementarea Noului Cod de procedură civilă, in Dreptul, nr. 9/2012

3. Chelaru E., Drept civil. Persoanele, C. H. Beck Publishing House, București, 2012

4. Deleanu I., Tratat de procedură civilă, vol. II, Universul Juridic Publishing House, București, 2013

5. Florian E., Dreptul familiei, Limes Publishing House, Cluj-Napoca, 2003

6. Frențiu G.C., Instanţa competentă să ia măsuri cu privire la relațiile de familie în lumina reglementărilor noului Cod civil şi ale noului Cod de procedură civilă, in Dreptul, nr. $12 / 2012$

7. Lupaşcu D., Crăciunescu C. M., Dreptul familiei - în noul Cod civil, $2^{\text {nd }}$ edition, Universul Juridic Publishing House, Bucureşti, 2012

8. Roşioru F., Dreptul individual al muncii, Universul Juridic Publishing House, Bucureşti, 2017

9. Ungureanu C.-T., Drept civil. Partea generală. Persoanele, Hamangiu Publishing House, Bucureşti, 2016

10. *** Law no. 17/2000 regarding social assistance for the elderly, republished in "Official Gazette of Romania", Part I, no. 157 of 6 March 2007

11. *** Law no. 487/2002 of mental health and the protection of people with mental disorders, republished in "Official Gazette of Romania", Part I, no. 652 of 13 September 2012

12. *** Law no. 272/2004 concerning the protection and promotion of the child's rights republished in "Official Gazette of Romania", Part I, no. 159 din 5 March 2014, with subsequent amendments

13. *** Law no. 304/2004 regarding the judicial organization republished in "Official Gazette of Romania”, Part I, no. 827 of 13 September 2005, with subsequent amendments 
Creț, D.C., (2019)

14. *** Law no. $273 / 2004$ concerning the procedure of adoption republished in "Official Gazette of Romania”, Part I, no. 739 of 23 September 2016

\section{Notes}

[1] C.T. Ungureanu, Drept civil. Partea generală. Persoanele, Hamangiu Publishing House, Bucharest, 2016, p. 345.

[2] Law no. 17/2000 on the social assistance for the elderly, republished in "Official Gazette of Romania”, Part I, no. 157 of 6 March 2007.

[3] Law no. 487/2002 of mental health and the protection of people with mental disorders, republished in "Official Gazette of Romania", Part I, no. 652 of 13 September 2012.

[4] Republished in "Official Gazette of Romania", Part I, no. 159 of 5 March 2014, with subsequent amendments.

[5] Republished in "Official Gazette of Romania”, Part I, no. 739 of 23 September 2016.

[6] In this regard, art. 8 of Law no. 272/2004 reiterates this aspect, stressing that, in any file on children's rights, the court must verify whether the agreements between parents or with other persons, observe the child's best interests.

[7] Republished in "Official Gazette of Romania", Part I, no. 827 of 13 September 2005, with subsequent amendments.

[8] G.C. Frenţiu, Instanţa competentă să ia măsuri cu privire la relaţiile de familie în lumina reglementărilor noului Cod civil şi ale noului Cod de procedură civilă, in Dreptul, nr. 12/2012, p. 98 and the following page.

[9] By the wording "the requests provided by this law" referred to in art. 84 paragraph (3) of Law no. 273/2004, there are to be considered applications such as: the request to open the adoption, the request to entrust the child for adoption, the application for approval of the adoption, the applications for annulment of the adoption etc.

[10] When the jurisdiction cannot be established according to these provisions, the Bucharest Court will have jurisdiction upon it.

[11] For a similar definition, see E. Chelaru , Drept civil. Persoanele, C. H. Beck Publishing House, Bucharest, 2012.

[12] E. Florian, Dreptul familiei, Limes Publishing House, Cluj-Napoca, 2003, p. 415; Al. Bacaci, C.V Dumitrache., C.C. Hageanu, Dreptul familiei, $7^{\text {th }}$ edition , C. H. Beck Publishing House, Bucharest, 2012, p. 328.

[13] F. Roşioru, Dreptul individual al muncii, Universul Juridic Publishing House, Bucharest, 2017, p. 342.

[14] T. Bodoaşcă, Unele consideraţii critice în legătură cu procedura divorţului în reglementarea Noului Cod de procedură civilă, in Dreptul, nr. 9/2012, p. 28-30; I. Deleanu, Tratat de procedură civilă , vol. II, Universul Juridic Publishing House, Bucharest, 2013, p. 722.

[15] D. Lupaşcu, C.M. Crăciunescu, Dreptul familiei - în noul Cod civil, $2^{\text {nd }}$ edition, Universul Juridic Publishing House, Bucharest, 2012, p. 404. 